\title{
Teresina [PI]: a capital planejada e sua indústria (1850-1920)
}

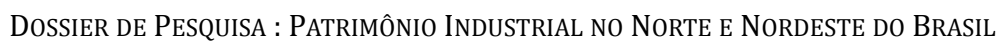

\section{Marina Lages Gonçalves Teixeira}

Arquiteta e Urbanista, Mestranda em Teoria e História da Arquitetura e Urbanismo pelo Instituto de Arquitetura e Urbanismo da Universidade de São Paulo. São Carlos [SP] Brasil. <marinalages@usp.br>

\section{Telma de Barros Correia}

Arquiteta e Urbanista, Professora Doutora. Instituto de Arquitetura e Urbanismo, Universidade de São Paulo. São Carlos [SP] Brasil. <tcorreia@sc.usp.br>

\section{Resumo}

O artigo mostra como a forma inicial de Teresina foi alterada pela expansão do comércio, dos serviços e da indústria. Detém-se na indústria, mostrando como a cidade abrigou um conjunto diversificado de fábricas, que contribuíram para uma mudança importante em sua forma urbana, pela geração de bairros operários e pela alteração da paisagem, com seus galpões e chaminés. Faz uma abordagem mais aprofundada da Companhia de Fiação e Tecidos Piauiense: sua origem, arquitetura, impactos na ocupação das terras em seu entorno e contribuição para o surgimento do bairro da Vila Operária.

\section{Palavras-chave}

Teresina. Indústria. Arquitetura industrial.

\section{Teresina [state of Piaui, Brazil]: the planned capital and its industry (1850-1920)}

\begin{abstract}
The article shows how the initial form of Teresina was altered by the expansion of commerce, services and industry. Holds in the industry, showing how the city housed a diverse set of factories, which contributed to a major change in its urban form, by the generation of working districts and by changing the landscape, with its sheds and chimneys. Take a deeper approach of Companhia de Fiação e Tecidos Piauiense: its origin, architecture, impacts on the land occupation in its surroundings and contribution to the emergence of the neighborhood of Vila Operária.
\end{abstract}

\section{Keywords}

Teresina. Industry. Industrial architecture. 


\section{Introdução}

O Piauí é, frequentemente, lembrado por sua economia agrária, ligada ao algodão e ao gado. Contudo, foi profundamente impactado pela Revolução Industrial, tanto pelo fornecimento de matériaprima - algodão, couro, etc. - para a indústria, quanto por ter gerado fábricas. Este trabalho explora este viés pouco conhecido do Piauí, tratando da relação entre a indústria e a capital Teresina. Procura mostrar como, esta cidade planejada que surgiu sob a égide do urbanismo da retícula e da higiene do século XIX, pensada para ser capital, foi também um importante centro de comércio e serviços e abrigou um conjunto diversificado de fábricas, que ofereceram contribuições importantes para a configuração de sua paisagem e forma urbana.

0 artigo traz alguns resultados de uma pesquisa de mestrado, em desenvolvimento, na área de Teoria e História da Arquitetura e do Urbanismo, no Programa de Pós-Graduação do Instituto de Arquitetura e Urbanismo da USP, orientado pela professora doutora Telma de Barros Correia. A pesquisa, apoiada pelo CNPq, tem enfoque na arquitetura industrial e ferroviária produzida na cidade de Teresina e é intitulada "Teresina (1890-1920): indústria, ferrovia e arquitetura".

\section{Teresina, seu Comércio e suas Fábricas.}

Fundada em 1851, Teresina seguiu um plano urbano regular composto por uma trama de ruas e cinco praças retangulares, que reuniam igrejas e prédio públicos. Esta primeira capital planejada do Império nasceu atendendo a anseios de desenvolvimento e articulação política e econômica do Piauí. Inserida na economia capitalista, logo perdeu o perfil inicial de cidade de cunho eminentemente administrativo. Entre o final do século XIX e começo do XX, se firmou como um centro de comércio e serviços com influência sobre o restante do Estado. A indústria se integrou à cidade de forma mais tímida, mas não deixou de causar profundos impactos em seu cotidiano e forma.

Em 1893 inaugurou-se, possivelmente, a primeira fábrica de porte da cidade de Teresina. Situada às margens do rio Parnaíba, a Fábrica de Fiações e Tecidos Piauiense foi mais uma iniciativa do grupo empresarial Casa Cruz. Integrava um "conglomerado piauiense" de empresas que surgiram a partir do capital gerado pela Estrada de Ferro Cajazeiras Caxias.

A fábrica causou impactos na forma urbana: impôs uma nova tipologia no cenário urbano e atraiu a moradia de seus funcionários para sua vizinhança, gerando um bairro industrial. Como era usual no nascimento da fábrica, o bairro que gerou assumiu uma forma irregular e foi povoado de moradias precárias, formando uma espécie de favela (ver mapa na Figura 1).

A essa época, a ocupação da cidade ainda se dava de forma mais concentrada nas margens do rio Parnaíba "nas duas ou três ruas paralelas à margem":

A área compreendida no espaço que ia da Rua Bela, atual senador Teodoro Pacheco, até a rua São Pedro e afastando-se um pouco da margem do rio, tudo era do domínio das casas comerciais conjugadas às residências dos seus donos ou gerentes. Tinha-se aí a cidade. Casas contíguas. Concentrava-se ali a população urbana até a altura da Rua Firmino Pires [...] (Monteiro, 1987b, pp.128-129).

O posicionamento da cidade entre rios, com seu centro fundacional voltado para o Rio Parnaíba, expressava o papel central da navegação e da comunicação na ordem urbana da cidade:

Teresina concentrou-se à margem do Parnaíba. A vida econômica, política e social [...] resplandece nas duas ou três ruas paralelas à margem do rio. Ali se comprava e vendia tudo. E nos escritórios das casas comerciais e das empresas fluviais, ou mesmo ao pé dos balcões, conversava-se, fazia-se política, intrigas, disse-disse (Monteiro, 1987b, p.127).

Não havia à época na cidade casas comerciais especializadas. "Os estabelecimentos tinham um sortimento variado, empórios, vendiam de tudo - do sabão à seda". Conforme o autor, os armazéns vendiam em grosso e a varejo, e alguns ainda somavam o este comércio o de exportação dos produtos regionais, como babaçu, cera de carnaúba, couro de boi e de outros animais (Monteiro, 1987b, p.128). 
As casas comerciais mais importantes estavam situadas à beira do rio Parnaíba e nas ruas próximas, entre as ruas Grande (atual Rua Álvaro Mendes) e São Pedro (ver mapa na Figura 1). Ocupavam prédios frequentemente conjugados às residências de seus proprietários e ou gerentes. Neste bairro se concentrava as moradias dos ricos comerciantes. Esta localidade foi o centro comercial até a ocorrência de duas grandes cheias, após as quais alguns comerciantes resistiram enquanto houve a predominância do transporte fluvial. Havia, ainda, outro eixo comercial, que estava se formando no Largo das Dores (Monteiro, 1987b, p.129).

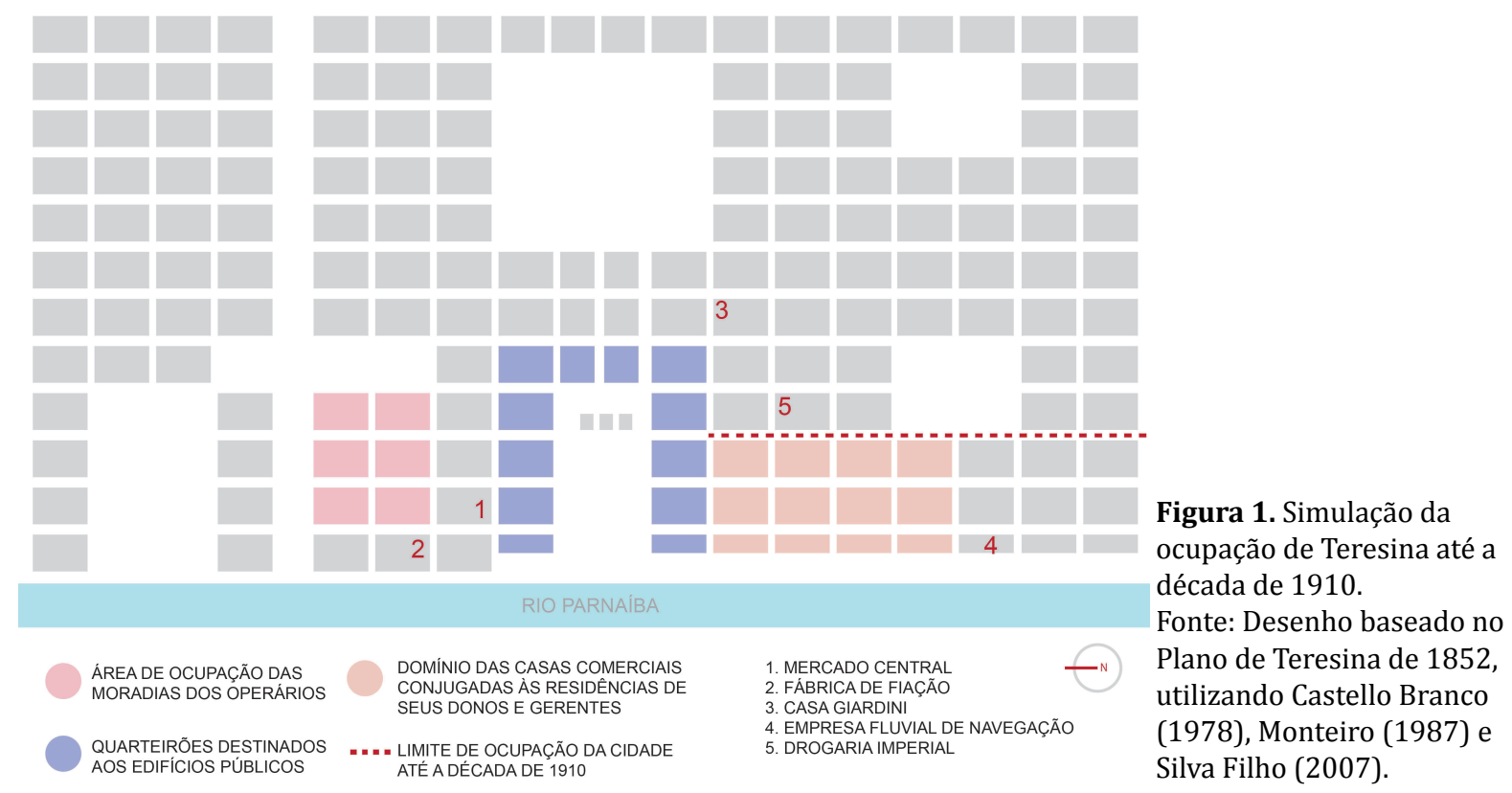

Sobre as casas comerciais piauienses, Silva Filho (2007b, p. 46) comenta: "a casa exclusiva de comércio foi se alojar preferencialmente nas esquinas e com menor apelo nos centros de quadra. É basicamente formada de salas com a maioria dos vãos externos compostos de portas". 0 autor ainda mostra como muitos desses estabelecimentos acabaram por se destacar na paisagem urbana, citando como exemplos em Teresina: o Bom Marché (1860); a Drogaria Imperial (1861); a Casa Cruz (primeira casa bancária, de 1880); a Londres na América (1885); e a Botica do Povo (1886). A estes prédios comerciais também se pode citar o da Casa Giardini, loja de joias pertencente ao imigrante italiano Horácio Giardini, instalada em um sobrado localizado na esquina da Rua Grande com a Rua da Graça (Castello Branco, 1978, p.22). A Drogaria Imperial, além de ser um sobrado, algo raro na arquitetura piauiense, possuía fachada revestida de azulejos, elemento também pouco utilizado. Segundo Moysés Castello Branco Filho (1978, p.22), "edificou-o o fazendeiro José Félix Alves Pacheco [...]. Fez vir de São Luís [MA] um mestre de obras para assentamento dos azulejos portugueses". A disposição dessas casas seguia algumas tendências:

Nas casas de residência e comércio a venda diferencia-se por uma maior quantidade de portas em relação à entrada única da residência, além da marcação com simulacros de colunas, denunciando essa setorização. O comércio é composto de 2 ou 3 salas, sendo a da esquina destinada à loja propriamente dita e outras para depósito de mercadorias. Há casas em que o comércio ocupa toda a lateral do lote, como a Casa Dôta [...]. O comércio se liga à parte doméstica através de passagem ao corredor de entrada, ou por um dos cômodos adjacentes à varanda de refeições. Quase sempre ocupam os lotes de esquina (Silva Filho, 2007b, p.48).

A indústria piauiense, apesar de seu pequeno porte, era bastante diversificada entre o final do século XIX e as três primeiras décadas do XX. Incluía fábricas de sabão, tecidos, bebidas, calçados, charutos, cigarros, gelo e vinagre, laticínios, cerâmicas, usinas de açúcar e indústrias de beneficiamento de algodão e arroz.

Orgmar Monteiro (1987b) relata que no Largo das Dores havia muitas mamoranas, árvores que davam frutos com sementes oleaginosas, que eram utilizadas na fabricação de sabão: [...] 
[...] as sementes de mamoramas pelo seu alto teor de óleo tinham um elevado preço para emprego na indústria caseira de sabões. Deixou de ser coleta ocasional e passou ao gênero extrativismo, comércio (Monteiro, 1987b, p.139).

Há registros de uma pequena fábrica deste artigo, denominada Saboaria Theresinense, de propriedade do Coronel João Broxado, possivelmente localizada na beira do Rio Parnaíba. No prédio da pequena fábrica da Saboaria Theresinense, vemos a utilização do óculo (ver Figura 2) para utilização de iluminação e ventilação naturais. A fachada apresenta esquadrias de verga reta - consideradas predominantes por Silva Filho (2007b) - e fechamento de tábua fechada com elementos de massa, pilastras e entablamento. É possível ver também a descida de água, possivelmente de elemento metálico, comumente incorporado às platibandas na arquitetura urbana piauiense: "buzinotes em chapas de zinco, mais conhecidos como boca-de-jacaré". A fachada simples com ausência de ornatos é coerente com o despojamento da arquitetura industrial.

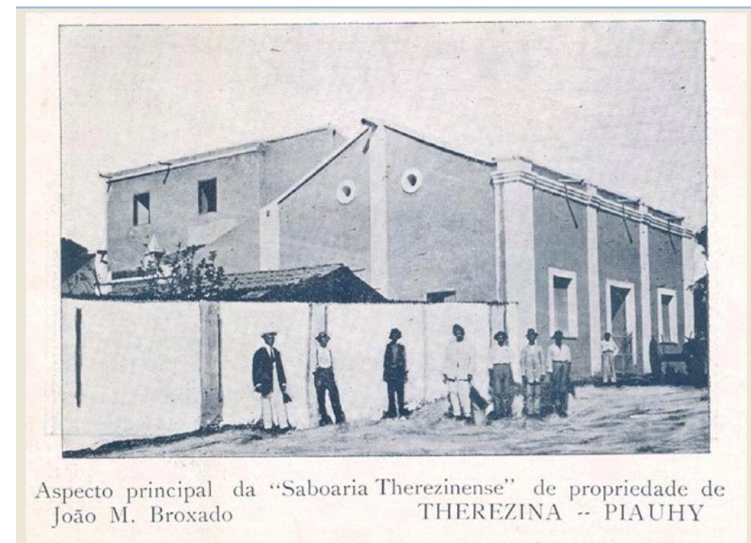

Figura 2. Saboaria Therezinense. Fonte: Acervo de Teresina Meu Amor (sem data).

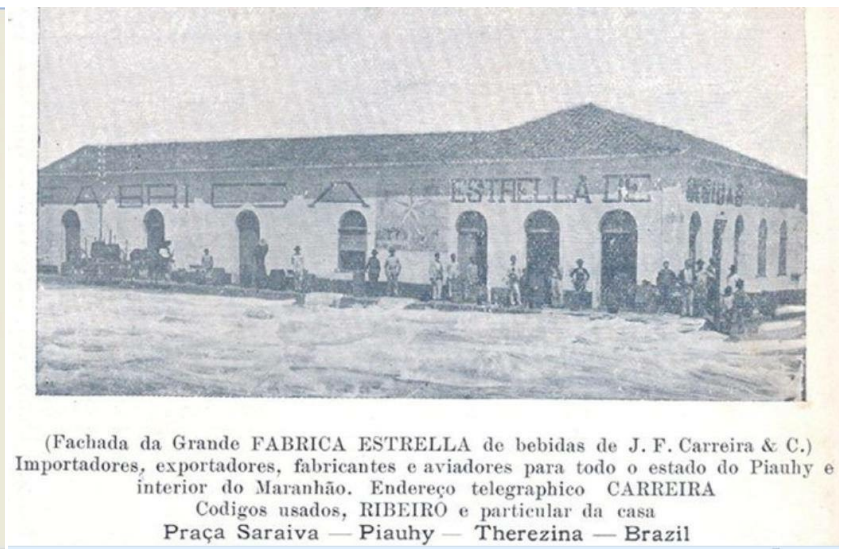

Figura 3. Fábrica Estrella. Fonte: Acervo de Teresina Meu Amor (sem data).

Monteiro (1987b, p.143) registra também o nome do senhor Álvaro Martins Gomes como proprietário de uma indústria "na primeira esquina paralela ao rio, pela Rua Félix Pacheco dos nossos dias". No Almanak Laemmert dos anos 1924 a 1927 é indicado o nome do senhor Gomes como proprietário de uma fábrica de bebidas. Já no ano de 1936, consta anúncio dos produtos fabricados guaranás, licores, vinhos, aguardente - e o registro de um endereço da Rua Siqueira Campos.

Na mesma lista de 1924 consta o nome de José Ferreira de Azevedo e J. C. Carreira \& C., como sócios de uma fábrica localizada na Praça Saraiva, o que coincide com os registros da Fábrica de Bebidas Estrella (ver Figura 3). A fábrica era bastante anunciada nos jornais piauienses - Gazeta, 0 Apóstolo e 0 Commercio - e teria sido premiada com "uma medalha de ouro na Exposição Nacional" (Acção Social, O Apostolo, 1909, p.3).

Em registros do Inventário de Proteção do Acervo Cultural do Piauí (IPAC PI) - promovido pela Prefeitura Municipal de Teresina, através da Fundação Cultural Monsenhor Chaves, em 1998 - há referência à Casa Pirajá, como exemplo de arquitetura industrial. Na ficha de registro, indica-se que seu proprietário utilizava a casa para uma antiga produção de charque e que aquela localização corresponde à casa de pólvora presente na planta da cidade de 1855. Achou-se o registro, em 1880, da contratação de "um barco com tripulação suficiente, para transportar, das Ilhotas para o Pirajá, a pólvora e mais materiais ali existentes" (Officios, A Imprensa, 1880a, p.2). Também se encontrou o registro, no mesmo mês, do pagamento ao "capitão encarregado do depósito de artigos bélicos o transporte de toda a pólvora e mais munições de guerra, das Ilhotas para o Sítio Pirajá" (Officios, A Imprensa, 1880b, p.5). Este uso, incompatível com a localização urbana, foi substituído.

Em 1908, o jornal 0 Apóstolo anunciou a inauguração da Escola Prática da Agricultura, localizada no sítio Pirajá. Tratava-se de um "centro de estudos práticos de lavoura", promovida a partir da Sociedade da Agricultura, que permitiria "assim ficar o Pirajá como ponto de experiência donde poderão provir os mais benéficos resultados e lições seguras da agricultura moderna" (Sociedade de Agricultura, O Apostolo, 1908, p.3). 
No ano de 1911, atendendo a recomendações do Ministério da Agricultura, o Governador Antonino Freire destinou o sítio ao uso como um "campo de demonstração" e sugeriu a criação conjunta de um "aprendizado agrícola que deveria ser um internato para 25 alunos" (Freire da Silva, Diario do Piauhy, 1911, p.4). No ano de 1912, o Pirajá consta na lista dos órgãos estaduais públicos, ao lado do Mercado Público, da Santa Casa e da Companhia das Águas (Imposto Predial, Diario do Piauhy, 1912). Noticiou-se em 1913, a instalação no local de um "campo experimental de borracha", onde [...]

[...] junto a casa ali existente, foi levantado um espaçoso galpão, que abriga muitos aparelhos próprios para as diferentes indústrias que no campo vão ser estudadas. Assim vimos arados, distribuidores mecânicos de adubos e sementes, diversos aparelhos para tratar a terra, alambiques, desnatadeiras, cortadores, debulhadores de milho \& \&. No almoxarifado vimos, igualmente, grande quantidade de utensílios para lavoura [...] (No Pirajá, Diario do Piauhy 1913, p. 2).

Provavelmente a Casa Pirajá, registrada pela Prefeitura Municipal de Teresina, esteja dentro dessa estrutura montada pelo poder público para amparar a agricultura e a indústria da borracha. Uma edificação simples, de implantação isolada no lote e com pouca ornamentação, que se assemelha às edificações das primeiras décadas da cidade. Na fachada, além de pilastras, há acima da porta de entrada um ornato sóbrio, onde o nome Pirajá aparece com uma flor de lótus.

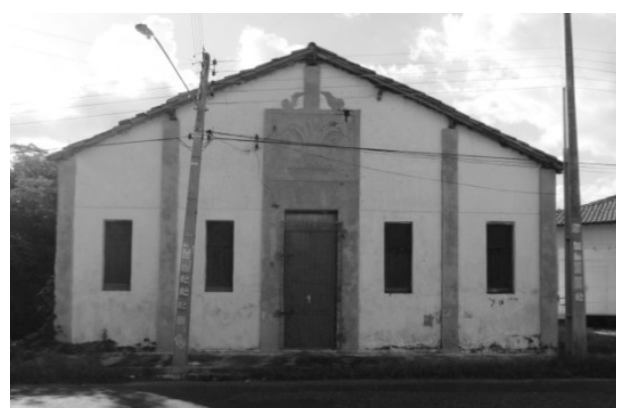

Figura 4. Fachada da Casa Pirajá Fonte: Acervo da autora (2015).

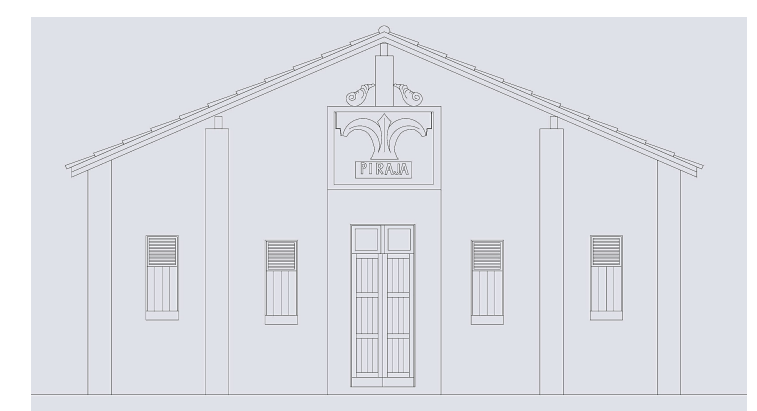

Figura 5. Fachada da Casa Pirajá Fonte: Acervo da autora (2018).

Segundo Silveira (2013), uma das primeiras indústrias do município, a Usina Santana, foi fundada em 1906, com a produção de álcool e açúcar. Estava anunciada no Almanak Laemmert do ano de 1935 como Engenho e Usina, supria as necessidades de consumo da cidade de Teresina e de regiões próximas. É considerada a primeira indústria sucroalcooleira do Piauí. Seu proprietário, Gil Martins Gomes Ferreira, também era um dos diretores da Fábrica de Fiação e da Companhia de Vapores (Lançamento, Diario do Piauhy, 1911). Para a venda e distribuição de seus produtos, possuía o único “depósito de açúcar de produção do estado" (Lançamento, Diario do Piauhy, 1912, p. 2).

Anos depois foi vendida a uma família de paraibanos, representados por Ivan e Francisco Santiago, que presenciaram o declínio da Usina, fundaram uma cerâmica homônima e, por fim, assistiram à sua falência (Silveira, 2013). As instalações de Usina eram compostas por dois grandes galpões modulados (ver Figura 6). 0 primeiro, e aparentemente o mais antigo, se apresenta com estrutura em vigas em concreto armado sem acabamento, pilares e fechamentos em alvenaria de tijolinho artesanal maciço e aparente.
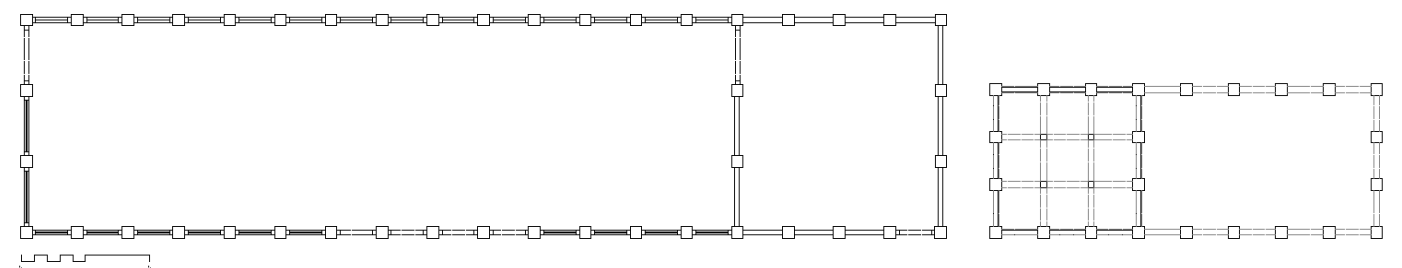

Figura 6. Planta Baixa dos grandes galpões da Usina. Fonte: Acervo de Marina Lages (2014).

A segunda ruína apresenta pilar em tijolo maciço com acabamento em reboco e pintura em cal; vigas em concreto armado; alvenaria também em tijolo maciço, com o mesmo acabamento; elementos vazados em concreto armado em peças de cinquenta por cinquenta centímetros; algeroz 
em placas de concreto e um letreiro com os dizeres "USINA SANTANA S.A." em elemento de cimento. A partir dos vestígios de sua cobertura, sabe-se que a mesma era escondida sob a casca do prédio e possuía estrutura metálica. 0 primeiro galpão tinha estrutura com vigas em concreto armado sem acabamento, pilares e fechamentos em alvenaria de tijolo artesanal maciço e aparente (ver fachadas nas Figura 7 e Figura 8).

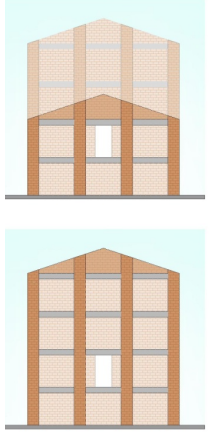

Figura 7. Levantamento das fachadas da Ruína 01. Fonte: Acervo de Marina Lages (2014).
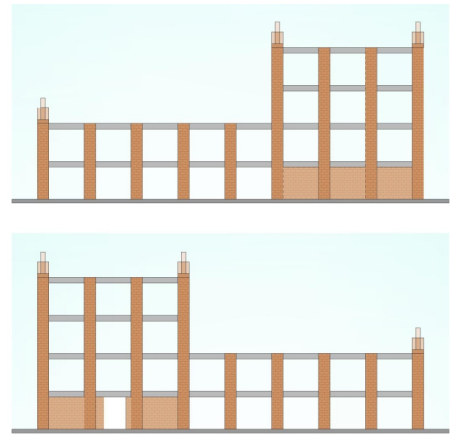

Figura 8. Levantamento das fachadas da Ruína 02.
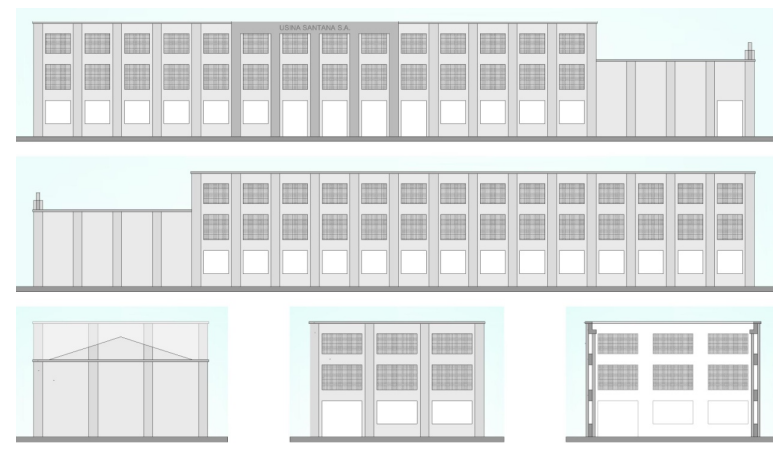

Fonte: Acervo de Marina Lages (2014).

A indústria - que em 1914 chegou a produzir mais de quatro mil sacos de $60 \mathrm{~kg}$ de açúcar e que, a partir de 1932, iniciou a fabricação de álcool empregando em torno de 400 pessoas - foi responsável pela formação de um aglomerado urbano em torno de suas terras, no qual seus funcionários moravam (Silveira, 2013). Suas dimensões e influência sobre a região são inegáveis. A população que reside no entorno da antiga Usina é composta, predominantemente, por ex-funcionários e/ou seus descendentes. Essa área faz parte da zona rural da cidade e é classificada pela Prefeitura Municipal como o Núcleo Urbano Santana:

Durante muito tempo ele foi relegado ao esquecimento por parte do poder público municipal. Suas origens, ligadas à Usina Santana $S / A$, parecem ter sido impedidoras de um maior beneficiamento da região, vista não como um bairro onde mora uma população carente de serviços públicos, mas como terras particulares daquele empreendimento (Silveira, 2013, p. 89).

\section{A Companhia de Fiação e Tecidos Piauiense}

Entre as fábricas instaladas em Teresina, no período tratado, a Companhia de Fiação e Tecidos Piauiense foi, sem dúvidas, a de maior impacto na vida e na paisagem urbana. Vinculava-se a uma das bases da economia do Estado, o algodão. No século XIX, a cultura de algodão avançou nas regiões secas do Nordeste, inclusive do Piauí, onde sua abundância suscitou a ideia de instalação de uma fábrica de tecidos. Assim, no final do século XIX, alguns comerciantes e proprietários reuniram-se em Teresina na tentativa de fundar uma companhia de fiação e tecidos. Como narra Monsenhor Chaves (2013):

A primeira tentativa para se instalar, em Teresina, uma fábrica de tecidos de algodão foi feita em 1874. Naquele ano um tal Sr. Benaion se propôs incorporar na cidade, uma companhia de tecidos. Aos 8 de março, no palácio do Governo, em mesa redonda composta do Presidente da Província e de vários cidadãos grados fez o Sr. Benaion uma exposição detalhada de seu plano. Exigia entre outras coisas:

1. O adiantamento de cem contos de réis para compra de máquinas e mais aparelhos da fábrica, edificação do prédio, etc;

2. Cem contos de réis em ações para ele pessoalmente, cujos lucros, influindo sobre os acionistas, tenderiam a diminuí-los consideravelmente;

3. Privilégio de exploração por 50 anos (Chaves, 2013, p.45).

Conforme Chaves, a proposta, considerada um "negócio da China" feita por um "espertalhão", foi rejeitada e derrotada por Polidoro Burlamaqui, David Moreira Caldas e Eugênio Marques de Holanda, que alegaram que não era compatível com os interesses da Província. Apenas uma pessoa foi a favor, Newton Burlamaqui (Chaves, 2013). Contudo, a ideia haveria de ressurgir após alguns anos. 
Em 1888, um grupo de comerciantes das cidades de Parnaíba e Teresina dirigiu-se à Assembleia da Província com a solicitação de isenção de impostos provinciais e municipais para uma companhia de fiação e tecidos, constituída a partir de "capitais de caxienses e teresinenses" (Monteiro, 1987c, p. 253). Quem assinava tal documento eram os senhores Antônio Gonçalves Pedreira Portelada, Joaquim Antônio dos Santos, Raimundo de Arêa Leão, João da Cruz e Santos, Mariano Gil Castelo Branco, Leocádio Alves dos Santos e José Alves dos Santos (Chaves, 2013).

Nesse mesmo ano, foi criada uma lei provincial de isenção de impostos sobre a importação de equipamentos e produtos, com vistas a facilitar a fundação da futura fábrica (Mendes, 2003). 0 jornal "A Imprensa", do dia 11 de agosto de 1888, transcreve a ata da 9a Sessão ordinária, de 12 de junho de 1888:

O Sr. Joaquim Britto, apresenta, como relator da comissão de fazenda, um projeto - que vai a imprimir sob no 30, concedendo a isenção de impostos provinciais e municipais à fábrica de fiação e tecidos que pretendem montar nesta cidade, os cidadãos Antônio Gonçalves Pedreira Portellada, João da Cruz e Santos e outros (Assembleia, A Imprensa, 1888).

Antônio Gonçalves Pedreira Portelada era o representante da, já citada, Casa Cruz na cidade de Teresina. 0 grupo iniciou suas atividades com a ferrovia Cajazeiras, depois investiu na navegação no rio Parnaíba, na prestação de serviços públicos com a Companhia de Águas e na fundação de uma indústria de fiação e tecelagem, aproveitando a experiência adquirida com a Fábrica União Caxiense, no vizinho estado do Maranhão.

O português Portelada ou Portela foi presidente das diretorias das companhias de Navegação a Vapor no Rio Parnahyba e de Fiação e Tecidos Theresinense, além de gerente do terminal de carga da Empresa Ferroviária e de Barcos. Um contemporâneo avaliou: "ninguém melhor do que ele tinha o descortino dos grandes negócios, operando com inteira segurança e admirável êxito" (Morto, 0 Apostolo, 1910, p.1). Através da imprensa, ainda no ano de 1888, anunciou-se a sociedade anônima criada com a pretensão de fundar uma fábrica, movida a vapor, de fiar e tecer algodão (Chaves, 2013).

Stein (1979) trata da condição da economia brasileira à época, onde o mercado de capitais era restrito e havia certo descrédito nas indústrias. Além disso, perdurou até a década de 1890, uma restrição e forte controle sobre as sociedades anônimas. Ainda assim, o setor se difundiu e "a forma de organização das manufaturas têxteis de algodão evoluiu da propriedade individual à sociedade e, finalmente, à corporação" (Stein, 1979, p.41).

No Piauí, anunciou-se que os interessados nas ações da fábrica que surgia deveriam procurar os representantes da mesma nas cidades de Teresina (Antônio Gonçalves Pedreira Portellada, João da Cruz e seu irmão), Amarante (José Ribeiro Gonçalves e Teodoro da Silva Ribeiro), União (Benedito José do Rego e Luís de Sousa Fortes) e Parnaíba (Joaquim Antônio dos Santos) (Chaves, 2013).

Com uma organização de sociedade anônima, foram oferecidas duas mil ações, cada uma valendo 100 mil réis, que seriam "realizáveis em prestações até $20 \%$ chamadas feitas com intervalo não menor de 30 dias de uma para a outra" (Chaves, 2013, p.82). Um grande número de piauienses investiu na empresa, como o médico Dr. Arêa Leão, parente de Portelada, principal investidor teresinense. Contudo, o controle acionário permaneceu nas mãos da família Cruz (Monteiro, 1987c). Esse fato coincide com o que Stein (1979) relata sobre o contexto nacional das indústrias têxteis, onde [...]

[...] a sociedade por ações não perdeu o caráter de empresa familiar, ou de empresa que envolvia a família ampliada, associados e amigos próximos. Essas relações pessoais tomaram possível a propriedade múltipla limitada por meio de sócios e diretores entrelaçados (Stein, 1979, p.43).

Ao final daquele ano, totalizaram-se 250 ações e os acionistas reuniram-se oficialmente no escritório da Companhia de Vapores. Portellada, deveria receber os valores correspondentes a um décimo das ações que foram vendidas num prazo de dois meses. José Pereira Lopes, juntamente 
com o capitão José de Castro e o tenente coronel Manoel da Paz, encarregaram-se de organizar os estatutos da Companhia, que só seriam aprovados em janeiro de 1889 (Chaves, 2013).

Em solenidades legais, constituiu-se a nova empresa piauiense e foi eleita sua diretoria: para presidente Major João da C. Lima e Almeida; para vice-presidente Dr. Cândido de H. Costa Freire; como secretários Cândido de H. Costa Freire, capitão Manoel Lopes Corrêa Lima e capitão Benjamim José Teixeira; como diretores Cel. João da Cruz e Santos, capitão Mariano Gil Castelo Branco, major Raimundo Antônio Lopes, tenente Gil Martins Gomes Ferreira e Antônio Gonçalves Pedreira Portelada; e para fiscais os Srs. Dr. Augusto Colin da Silva Rios, Dr. Collect Antônio da Fonseca e João de Morais Rêgo (Chaves, 2013). Barbosa (1991) afirma que no mesmo ano de 1889 os estatutos e o local onde seria instalada a fábrica foram aprovados. Monteiro (1987c) afirma que o projeto de construção foi apresentado às autoridades e admitido com entusiasmo: "o local seria além da Rua da Estrela, na beira do rio Parnaíba" - "a última rua do perímetro da cidade projetada por Saraiva", na Baixa do Poço (Monteiro, 1987c, p.254 e 255). Meses depois, em 30 de agosto, foi lançada a pedra fundamental (Barbosa, 1991), com a benção cônego Honório Saraiva e discurso de Sousa Lima (Chaves, 2013).

O maquinário da fábrica foi, provavelmente, encomendado da Inglaterra (Barbosa, 1991), para onde foi enviada a quantia de 23 contos de réis e logo após mais 120 (Chaves, 2013). Ao que tudo indica, além das máquinas, implementos e peças de reposição são de fabricação inglesa, assim como a estrutura do prédio - "as colunas cilíndricas de ferro, o teto em vigas de aço e calhas do mesmo material, que ainda podem ser vistas, conferidas e aferidas" (Monteiro, 1987c, p.254). Os pilares metálicos do prédio da fábrica são todos identificados com o nome da Henry Rogers Sons \& Co, citada por Stein, e trazem grafados também “Wolverhampton - England", cidade inglesa onde essa empresa estava instalada.

No final do século XIX, os produtores de maquinário começaram a buscar encomendas no Brasil e passaram a anunciar nos jornais seus produtos. Conforme Stein, "à frente de todos estava a Henry Rogers Sons \& Co.". "Esses agentes das indústrias de máquinas europeias e americanas eram procurados pelos empresários brasileiros que necessitavam de projetos, máquinas e conselhos técnicos para suas fábricas" (Stein, 1979, p.50).

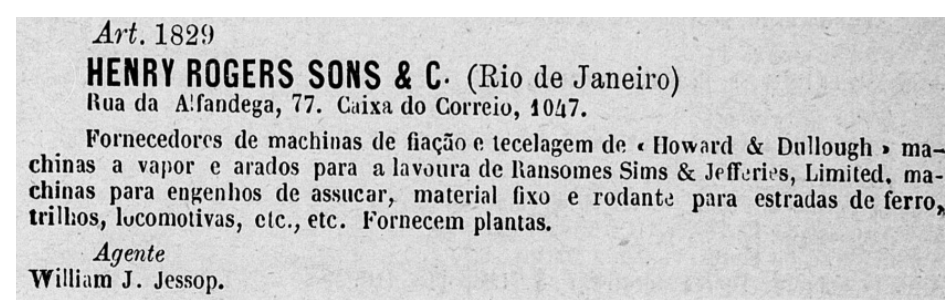

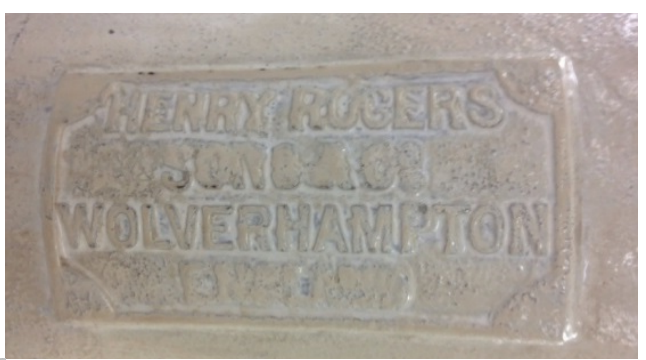

Figura 9. Marcação nos pilares metálicos HENRY ROGERS SONS \& CO WOLVERHAMPTON — ENGLAND Fonte: Acervo da Autora (2017).

Figura 10. Anúncio da Henry Rogers Sons \& Co. Fonte: Almanak,1891.

Os anúncios da Henry Rogers \& Co. ofereciam máquinas para a indústrias têxteis e açucareira, instrumentos para a lavoura e diversos equipamentos para as ferrovias (ver figura 10 acima). A empresa informava ter sua casa matriz em Wolverhampton e suas filiais em Londres, Liverpool, Sheffield e no Rio de Janeiro. Além disso, constava nos anúncios que forneciam plantas (Almanak, 1891). Estas circunstâncias, unidas ao fato dos diretores da Fiação de Teresina terem anunciado nos jornais uma lista detalhada de materiais de construção de que necessitavam para a construção da mesma, pode demonstrar que o projeto viera pronto da Inglaterra, com a especificação de todos seus elementos (Figura 11 e Figura 12).

Apesar de tais evidências indicarem a possibilidade da planta ter sido fornecida pela empresa citada, na listagem dos materiais de construção temos a presença da carnaúba, "o maior e mais usado material de construção no Piauí. Até bem pouco tempo podia-se afirmar que a construção no território piauiense era de carnaúba" (Barreto, 1975).

Enquanto se esperava a chegada do material importado, foram iniciadas as providências dos demais: a areia podia ser extraída do rio, logo ao lado; as pedras destinadas aos alicerces estavam 
presentes no próprio terreno. A cal era trazida via estrada de ferro das minas de Caieiras, próximas ao Engenho D'Água, em Caxias, que eram de propriedade da Casa Cruz. Os tijolos podiam ser encomendados às olarias da Vila do Poti Velho, mas nesse caso, o problema encontrado foi o transporte:

Se fosse por terra o carro de boi retardaria a obra pela sua natural lentidão; se fosse por água, os botes ou barcas carregadas teriam o gravame da corrente do rio obstaculizandolhes a subida. A melhor solução seria construir os tijolos a montante, em local escolhido (Monteiro, 1987c, p.256).

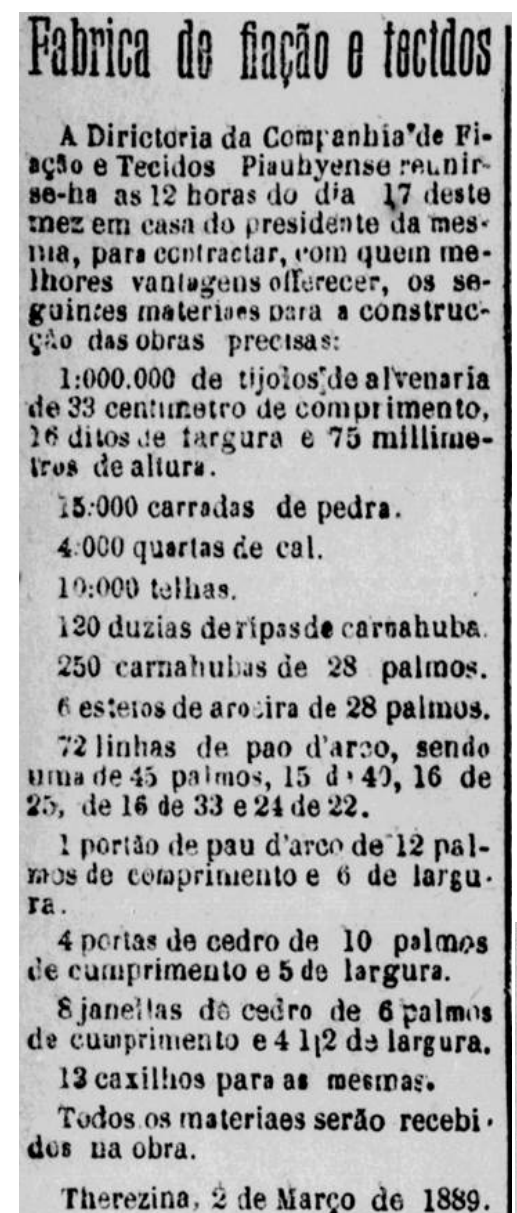

Therezina, 2 de Março de 1889.
Figura 11. Anúncio da diretoria da fábrica em 1889.

Fonte: Fabrica, A Phalange, 1889.

A Diretoria da Companhia de Fiação e Tecidos Piauhyense reunir-se-á as 12

horas do dia 17 deste mês em casa do presidente da mesma, para contratar, com quem melhores vantagens oferecer, os seguintes materiais para a construção das obras precisas:

1:000.000 de tijolos de alvenaria de 33 centímetros de comprimento, 16 ditos de largura e 75 milímetros de altura,

15.000 carradas de pedra,

4.000 quartas de cal,

10.000 telhas,

120 dúzias de ripas de carnaúba,

250 carnaúbas de 28 palmos,

6 esteios de aroeira de 28 de palmos,

72 linhas de pau d'arco, sendo uma de 45 palmos, 15 de 40, 16 de 25, de 16 de 33

e 24 de 22 ,

1 portão de pau d'arco de 12 palmos de comprimento e 6 de largura,

4 portas de cedro de 10 palmos de comprimento e 5 de largura,

8 janelas de 6 palmos de comprimento e 4 e meio de largura,

12 caixilhos para as mesmas,

Todos os materiais serão recebidos na obra.

Therezina, 2 de Março de 1889.

A Directoria da Companhia de Figura 12. Anúncio da diretoria da fábrica em Fincüo e Tecidos Piauliyense 1890. Fonte: Directoria, Estado do Piauhy, 1890. coingra os seguintes materiaes:

Linhias de nan d'arco de 30 a 50 palmos de comprimento e de 8 a 10 pollegadas de quina, (am:go).

Soleiras de aroeira o pau d'ar. co de 10 a 12 palmos de compri. mento, 16 pellegacis de largura e

5 ditas do grossura.

Ripas de cedro de 25 palınos

de comprineato 4 pollegadas de

largura e $3 / 1$ pollegadas de gios. sura.

Taboas-cedro do muito bôa qualidade do 15 a 20 palmos de comprimento, de 1 a 2 de largura e 2 püllegadas de grossura.

Tijolli.s de alven iria' de 33 cen. tim tros de comprinento 16 do lsrgura e 75 ailimetros de gros surs.

Theresina,10 de Março i̇ 1890 Theresina, 10 de Março de 1890.
A Diretoria da Companhia de Fiação e Tecidos Piauiense compra os seguintes materiais:

Linhas de pau d'arco de 30 a 50 palmos de comprimento e de 8 a 10 polegadas de quina, (amago).

Soleiras de aroeira e pau d'arco de 10 a 12 palmos de comprimento, 16 polegadas de largura e 5 ditas de grossura.

Ripas de cedro de 25 palmos de comprimento, 4 polegadas de largura e $3 / 4$ polegadas de grossura. Tábuas-cedro de muito boa qualidade de 15 a 20 palmos de comprimento, de 1 a 2 de largura e 2 polegadas de grossura.

Tijolos de alvenaria de 33 centímetros de comprimento, 16 de largura e 75 milímetros de grossura.

A solução encontrada foi a fabricação dos tijolos nas proximidades do prédio a ser construído. 0 terreno à montante não serviria, pois era um desaguadouro natural - uma voçoroca, chamada Barrocão; e à beira rio, localizavam-se lagoas ciliares, inundáveis até nas pequenas cheias e impossíveis de drenar. A olaria, então, situou-se na Quinta Parangaba:

O terreno sólido e elevado alcançava o rio. [...] Havia o maciço de rocha entre as terras baixas dos leitos abandonados o qual oferecia um porto praticamente sem remoção terrestre, com pouco transporte. A olaria seria instalada, ao abrigo da eventualidade de uma 
enchente. A argila explotada na lagoa iria para os oleiros nos barrocões onde a cerâmica secaria para a queima posterior (Monteiro, 1987c, p.257).

O trabalho de produção de tijolos era feito em "ritmo industrial" em galpões cobertos por palha, onde os tijolos e telhas secavam à sombra "no verão e no inverno". Depois do cozimento eram levados, através do rio, ao canteiro de obras (Monteiro, 1987c, p.258). As obras se prolongaram e foram objeto de comentários entre a população e através da imprensa, onde avaliações céticas sobre o empreendimento foram publicadas. Chaves (2013) traz um exemplo:

\author{
Existe aqui certa empresa, \\ Já com grande capital, \\ Cujos negócios vão indo \\ Parece que muito mal; \\ Hão feito tal embrulhada \\ Que já se diz com razão: \\ - "Ninguém se pode FIAR \\ Nos homens da FIAÇÃO". \\ Em aplanar o terreno \\ Sem terreno ainda em PLANO \\ Parece que vão fazendo \\ Daquilo um circo romano. \\ E o diretor dessa obra \\ Já querem chamar de louco: \\ Descobriu a QUADRATURA \\ DO CIRC'LO, já não é pouco.
}

(Chaves, 2013, p.83)

Enquanto as obras atrasavam, grande parte do terreno destinado à fábrica permanecia uma lagoa: "Tudo isto irrita o povo que gosta de pressa no andamento das obras que o interessam" (Chaves, 2013, p.84). A construção, contudo, foi concluída e tornou-se um marco na paisagem urbana da cidade e no cotidiano dos moradores de Teresina. No relato de Monteiro (1988b) sobre suas memórias da infância nos anos 1920, consta:

Em minhas idas eventuais até a Fiação, com meu pai, ou acompanhando a minha mãe quando ela ia ao mercado, via o que se passava no canteiro-de-obras em que se transformara aquela vasta área da nossa cidade. Tudo aquilo que se construía foi retido no meu consciente. Nada entendia do que faziam. Era a movimentação. O frenesi. Muitos homens trabalhavam. Contornar a área para chegar ao mercado era uma rotina. Na transformação mudaram o cruzeiro de lugar e a crendice popular arguia com o post hoc, em razão do poder sobrenatural responsabilizado por infaustos havidos subsequentes ao fato de mudarem o símbolo da fé e da cidade, donde ficara primitivamente implantado (Monteiro, 1988b, p. 422 e 423).

A fábrica só começou a funcionar em 1892, três anos após a instalação das máquinas e conclusão da construção da chaminé (Barbosa, 1991). 0 funcionamento se deu em forma experimental, antes da inauguração, trabalhando a pleno vapor seis teares:

Continua na experiência de suas máquinas, a Fábrica de fiação, e o êxito que tem obtido essas
experiências faz augurar um próximo e completo funcionamento de todo o maquinismo. Não
se poderá ainda bem determinar a época de inauguração solene dos trabalhos da fábrica,
mas é intuito de seus diretores realizarem este desideratum o mais breve possível, fazendo
retirar logo da produção perfeita do pano, as vantagens inauferíveis para aqueles que tem
empregado os seus capitais (Fabrica, A Legalidade, 1892, p.4).

0 resultado agradou o mercado local: "o tecido é tão bom e perfeito que comerciantes de Caxias propõem, logo, a compra de todo o produto de um semestre. As ações sobrem para $140 \$ 000$ e não se acha quem as queira vender" (Chaves, 2013, p. 83).

A inauguração oficial deu-se em primeiro de janeiro de 1893, com a benção do cônego Honório Saraiva à máquina motora, que recebeu o nome de "Cristino". No evento apresentaram-se as bandas do Corpo de Segurança e do 35ª Batalhão de Infantaria (Chaves, 2013): 
Foi dia de festa, com muita música, foguetes e bebidas. Segundo consta, à noite, na residência do Barão de Uruçuí, um dos proprietários, houve baile para os operários da fábrica (Barbosa, 1991, p. 41).

Durante suas seis décadas de funcionamento a fábrica, que era administrada por maranhenses, teve papel importante na economia da cidade e na inserção da mulher no mercado de trabalho (Lima; Santos, 2014). 0 setor têxtil foi o ramo industrial que mais empregou mão de obra feminina. Referindo-se ao Brasil, Stein (1979) trata da avaliação usual das mulheres como operárias mais ativas que os homens. Magalhães (2006) mostra que desde a produção caseira de panos até as fábricas, as mulheres formaram a maioria da mão de obra, embora os cargos mais altos fossem ocupados por homens. Sobre as mulheres operárias da Fiação, Monteiro (1987c, p. 270) relata que os moradores da região da fábrica eram acordados ainda de madrugada pelo "vozeiro das tecelãs", que foram apelidadas de "pipiras":

O apelido pegou. Generalizou-se. Naqueles tempos da Fiação o título de pipira passou a ser status; graduação social; acima de criada, serva ou doméstica para as empregadas nas casas dos ricos que podiam manter serviçais sob remuneração. Orgulhosamente se designavam pipiras.

Monteiro (1987c) informa que o horário de trabalho da fábrica ia do nascer ao por do sol - das seis da manhã às seis da tarde - somando doze horas de jornada diária. Stein (1979) mostra que as fábricas brasileiras da época declaravam e algumas recomendavam turnos de apenas dez horas diárias, em seis dias por semana. Contudo, com o advento da luz elétrica, as jornadas foram alongadas, chegando a catorze ou dezessete horas por dia. Para Hardman e Leonardi (1989, p.179) no setor têxtil se encontravam os "casos limite de jornadas mais intensas". À exploração, se associava ao trabalho de mulheres e crianças em grande número:

Submetendo por completo a família proletária às condições da produção fabril. Tal procedimento combinava-se com um alto grau de mecanização da fábrica (energia a vapor e teares), o que ampliava a produtividade do trabalho. Esse processo combinado acarretava o crescimento do exército industrial de reserva e a desvalorização da força de trabalho, fazendo com que o setor têxtil apresentasse as taxas mais baixas de salário, com relação aos ramos do vestuário, metalurgia e calçados, estando, em 1919, acima apenas do setor de produtos alimentares (Hardman \& Leonardi, 1989).

Sobre a remuneração dos operários, "os fabricantes diziam, com frequência, que a força de trabalho era barata, e a presença de um grande número de mulheres e crianças nas fábricas parece confirmar isso" (Stein, 1979, p.74), Tal sistema exigia, muitas vezes, o engajamento de vários membros da família no trabalho, "submetendo por completo a família proletária às condições da produção fabril" (Hardman; Leonardi, 1989, p.179). Em 1919, no Brasil, o setor têxtil, apresentava menores taxas de remuneração em relação aos setores de vestuário, calçados e metalurgia; ficando acima apenas da produção de alimentos (Hardman; Leonardi, 1989).

Monteiro (1987c) relata cenas do dia a dia da fábrica onde um dos diretores se utilizava das vistorias para observar as jovens operárias:

Um dia o diretor faz um passeio pela sala dos teares. Não era novidade. A inspeção do acabamento do tecido era rotina adotada pelo interesse do próprio objetivo comercial. Porém, de par havia o olhão do curioso descobrindo as pipiras [...] (Monteiro, 1987c, p.277).

0 relato em questão introduz a história de uma moça operária "Alva, loura e bonita. Devia ter 15 a 16 anos. Quase infantil" que engravida a partir do envolvimento com seu patrão casado (Monteiro, 1987c, p.278). Nos jornais, foi noticiado o caso de um oficial do corpo de segurança da cidade que ao visitar a fábrica "interrompeu o trabalho de uma operária, fazendo-lhe desabridamente a corte" e quando advertido pelo mestre, sacou sua arma ameaçando a todos (Vallente, A Legalidade, 1892, p.4). São exemplos do que Hardman (1989) menciona sobre as rotineiras denúncias de abusos e violências sexuais contra meninas e mulheres na indústria têxtil.

Contudo, a indústria era tratada com muita simpatia pela imprensa local. A importância ela atribuída pode ser constatada nos jornais da época, onde acontecimentos na fábrica e seus trabalhadores 
eram constantemente noticiados. 0 coronel José João dos Santos, funcionário que assina os anúncios, era saudado pelas colunas como "operoso gerente"; o major J. Antonio de Lima e Almeida como o "laborioso guarda-livros" e "operoso funcionário"; o dr. Elias Martins, diretor da empresa, era tratado como "nosso chefe". Os jornais noticiavam, inclusive, decisões internas da empresa, como a renúncia do diretor Elias Martins em 21 de agosto de 1910 e seu imediato desligamento (Directoria, 0 Apostolo, 1910). Aniversários e morte dos dirigentes eram noticiados, como a do coronel Antonio Gonçalves Pedreira Portellada, onde um resumo da sua trajetória de vida e profissional foi publicado em homenagem feita pelo jornal 0 Apóstolo.

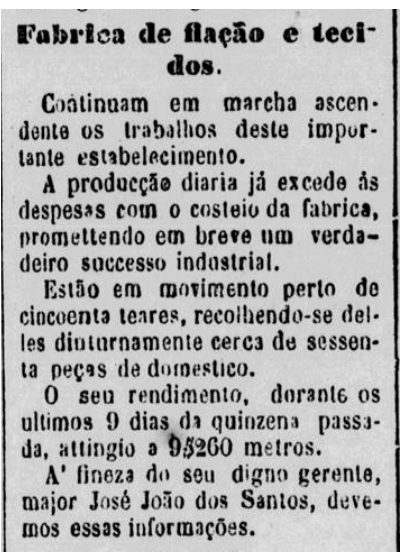

Figura 13. Anúncio da fábrica sobre sua capacidade de produção. Fonte: Fabrica, A Legalidade, 1892.

Figura 14. Tabela de preços dos produtos. Fonte: Fiação, A Legalidade, 1892a.

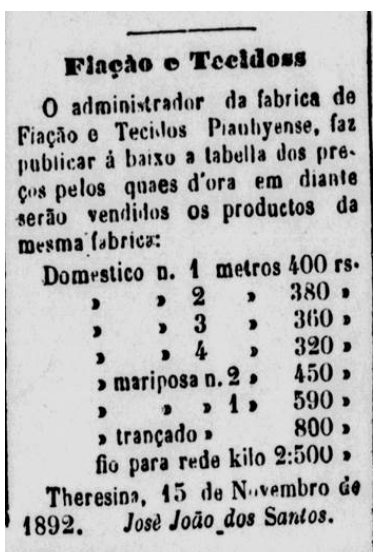

Rodrigues (2001) atribui ao aparecimento, nas primeiras décadas do século XX, de vendedores-viajantes e representantes comerciais do sul do país, a falência de várias empresas de Teresina, como a Tabacaria Ipiranga e a fábrica de tecidos, que não teriam resistido à concorrência. A concorrência com empresas de outros estados foi certamente um dos fatores responsáveis pelo fechamento da empresa. Contudo, um estudo mais aprofundado sobre o tema, poderia avaliar a ação de outros fatores. Monteiro (1987c) fala na morte do Senhor Zés, o patriarca da família Cruz e "cérebro e braço forte que sustentou a estrutura até a década do século atual" (século XX), como "o começo do fim". A partir do final dos anos 1920, a fábrica teria, em sua opinião, passado para a direção de pessoas de menor preparo, levando a um declínio (Monteiro, 1987c, p.260). Na década de 1920, o Doutor Mundico Arêa - neto de Portellada - reuniu, com ajuda de sua mãe — Dona Joaninha — as ações de seu avô e montou um plano de recuperação das finanças da fábrica, que foi apresentado aos demais acionistas como uma "nova fase de esplendor agitou a velha Fiação" (Monteiro, 1987, p.260).

Barbosa (1991), por sua vez, data o fechamento da indústria no ano de 1930. Contudo, a fábrica continuou em funcionamento. Acredita-se que tenha apenas interrompido suas atividades, por algum tempo, devido às duas grandes enchentes que aconteceram na década de 1930 (Figura 15). Na enchente de 1924, que durou duas semanas, as águas do rio Parnaíba subiram lentamente no prédio, o que "permitiu ensaios de defesa com diques nas portas" e "foi feito o transbordo do escritório pela janela da Rua João Cabral [...] que permitiu retirar o que havia de mais precioso e perecível" (Monteiro, 1988b, p.322 e 330).

Dois anos mais tarde, ocorreu na cidade uma inundação maior e mais rápida: "as ruas da Estrela (Des. Freitas) e João Cabral eram navegáveis [...] Não houvera tempo de salvar nada. A velha Fiação estava inundada". 0 nível da água subiu até a Rua Barroso, cinco quarteirões acima da Rua das Pedras - atual João Cabral - e três quarteirões acima da Rua Firmino Pires - o limite de ocupação da cidade à época (Monteiro, 1988b, p.330). Com a rapidez da cheia e o volume de suas águas "as casas à margem do rio todas desabaram, totalmente ou em parte. Alicerces cederam. Paredes racharam. Resistiram incólumes: prédios e muros da Fiação, a casa de bombas da Cia. De águas e a Usina Elétrica" (Monteiro, 1988b, p.331). Depois da cheia de 1926, o primeiro centro comercial de Teresina entrou em declínio e foi praticamente todo transferido para outra região, mais alta e distante do rio Parnaíba. Monteiro (1988b) associa esse fato à decadência do transporte fluvial.

Com o início da Segunda Guerra, em 1939, as "pequenas indústrias do norte do país que tinham sobrevivido" - como a Fiação, de Teresina, a União Caxiense, a Sanharó, de Caxias e a de Codó (pertencente à família Archer) - voltaram a funcionar, quando empresários "do sul" buscaram recuperar velhas fábricas, comprando ações para comandá-las. Nessa época a Fiação teve donos sucessivos (Monteiro, 1987, p.262). 


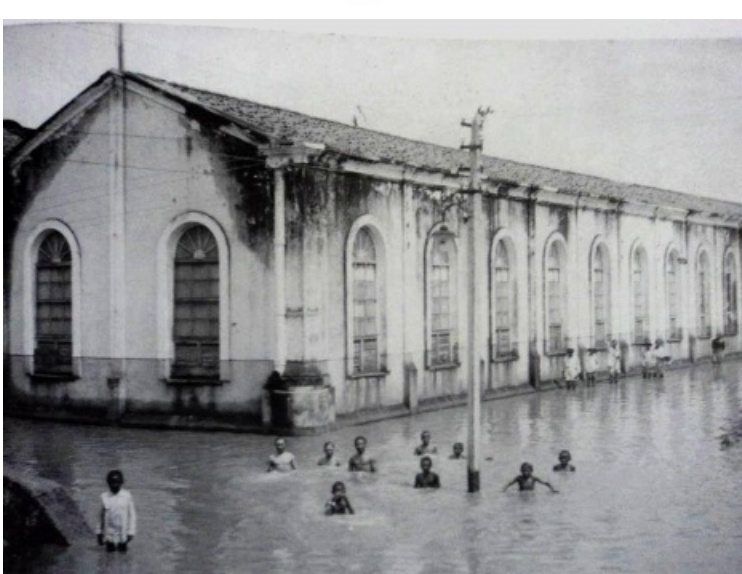

Figura 15. Enchente na década de 30. Fonte: Acervo da Fundação Monsenhor Chaves (FMC).

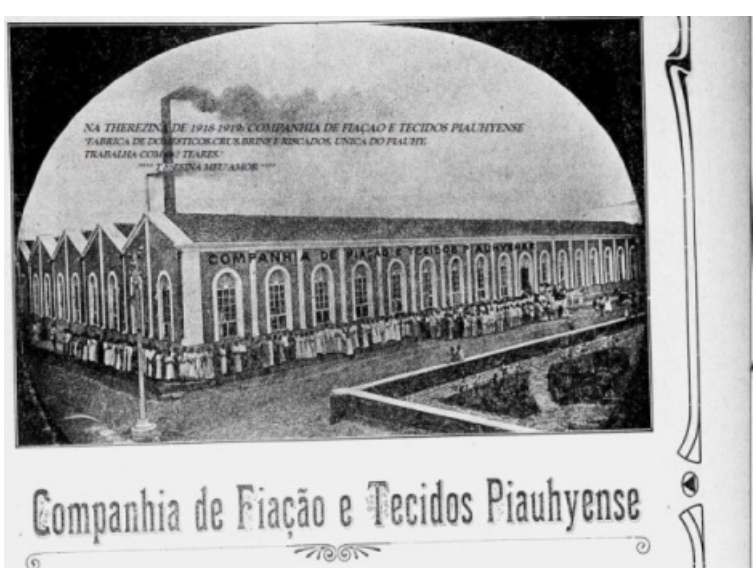

Figura 16. Registro mais antigo encontrado, supostamente do ano de 1918. Fonte: Acervo da FMC.

No pós-guerra, muitas indústrias locais passaram por dificuldades:

A Fiação nos anos 50 era a mole rolando para o abismo pelo plano inclinado da insustentabilidade financeira. Insolvência. Estágio de pré-falimento. 0 mal não foi exclusivamente dela. As suas congêneres de Caxias, Codó e São Luiz formaram um bloco de massa falida. No Ceará, Pernambuco e outros Estados do Nordeste as quebras de fábricas de fiação e tecelagem daquele período eram sucessivas (Monteiro, 1987c, p.264).

A essa época, o libanês Yared adquiriu a parte majoritária das ações da Fiação, mas logo foi à falência. Mendes (2003) data o fechamento da fábrica no ano de 1957. 0 Banco do Brasil assumiu a administração e os operários teriam o privilégio do crédito, mas a venda das máquinas e demais posses não foi suficiente para solucionar as dívidas da empresa. Monteiro (1987c) relata que o imóvel passou por diversos proprietários até chegar ao Grupo Claudino, na década de 1990, segundo Barbosa (1991).

A edificação que foi ocupada pela Fiação está em uma esquina, com suas fachadas voltadas para as ruas Desembargador Freitas e João Cabral - antigas ruas da Estrela e das Pedras, respectivamente - no que é hoje o coração do centro histórico da cidade de Teresina. 0 prédio encontra-se no primeiro núcleo central de povoamento da cidade, nas proximidades do Mercado Velho, da Praça da Bandeira e da Igreja Matriz e é, possivelmente, o último testemunho de exemplar das fábricas de fiação e tecelagem do estado do Piauí.

A locação e implantação da fábrica no terreno tem por justificativa a posição estratégica em relação ao rio, onde se transportava materiais de construção, algodão, lenha e se escoava a produção:

A fábrica e o muro do pátio foram construídos à margem do rio. Na ribanceira. Isto era uma posição adrede para carga e descarga por força do transporte fluvial. O portão que abria do lado do rio, logo depois da esquina da Rua Des. Freitas, dava acesso à lenha diretamente em frente das caldeiras gerando vapor para as máquinas. Do lado esquerdo havia comunicação interna para o pátio onde empilhavam esse combustível (Monteiro, 1987c, p.260).

A imagem mais antiga que se tem registro da Fábrica de Fiações é supostamente datada em 1918 ou 1919 (Figura 15). Nela a cor escura das paredes externas do prédio, sucinta a dúvida sobre o uso, em um período inicial, do tijolo aparente. Nas demais imagens posteriores vê-se, claramente, o uso do reboco com pintura.

O suposto uso do tijolo aparente nos remete à linguagem despojada utilizada nos prédios fabris. Uma linguagem coerente com preceitos próprios do mundo fabril, como funcionalidade, eficiência, utilidade e economia (Correia, 2011, p. 27). Algo também relativo a essa linguagem arquitetônica são os amplos galpões e as altas chaminés. A da Fiação tinha "120 palmos ingleses de altura" (Chaves, 2013, p. 83). A essas características, se somavam os novos programa e soluções estruturais, além do próprio tamanho das unidades fabris (Correia, 2011). 
Os prédios fabris produzidos no Brasil possuíam costumeiramente um ou dois pavimentos; ao contrário dos ingleses que constavam com vários (Correia, 2011). 0 prédio que abrigou a Fiação tem apenas um andar, com um alto pé direito, variando entre 5,25 e 7,02 metros. É formado por quatro galpões, de oito águas. Tem uma área de cobertura de mais de dois mil metros quadrados. É uma construção ampla, cujo exterior sugere quatro galpões alongados, acoplados.

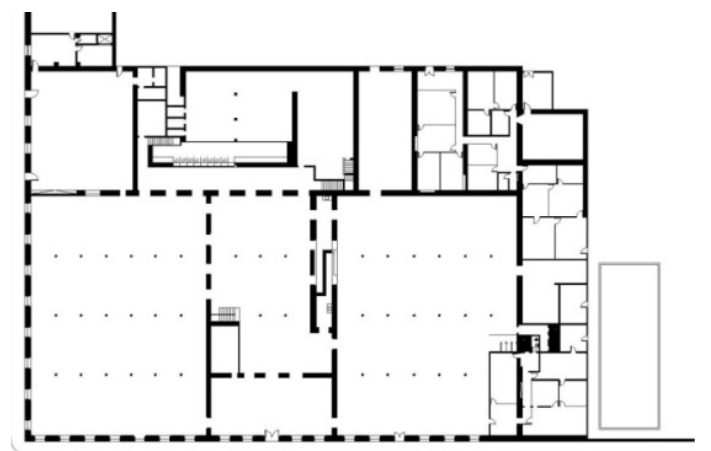

Figura 17. Planta Baixa da edificação. Fonte: Acervo do Grupo Claudino, manipulado por Marina Lages (2017).

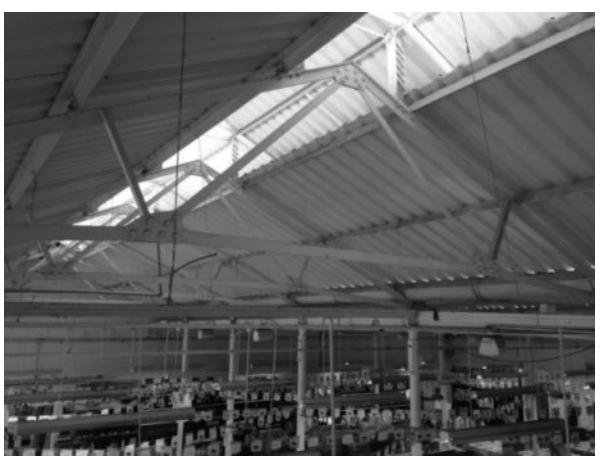

Figura 18. Estrutura em tesouras metálicas e lanternim. Fonte: Acervo de Marina Lages (2017).

O prédio da Fiação segue a tendência, apontada por Correia (2011, p. 132), da construção industrial em tijolo, dotada de inovações no campo construtivo e formal. Uma delas são as estruturas metálicas que permitiam grandes vãos. Outra são amplas janelas e lanternim, relacionadas a preocupações de ventilação e iluminação.

A Figura 18 apresenta uma noção da amplitude dos galpões colados construídos em alvenaria de tijolos, dos grandes vãos permitidos pelo uso de pilares, vigas e tesouras em ferro fundido que suportavam a cobertura de telha cerâmica.

Na linguagem despojada que penetra o mundo fabril, além do tijolo aparente, o ferro ganha expressão - em componentes estruturais e em sistemas hidráulicos - nos interiores e nas fachadas (Correia, 2011). No prédio da Fiação, as calhas e tubulações de descida de água foram mantidas aparentes na fachada, integradas ao desenho das pilastras (Figura 19). Seu exterior confirma a tendência ao uso limitado de ornatos, típica dos prédios fabris:

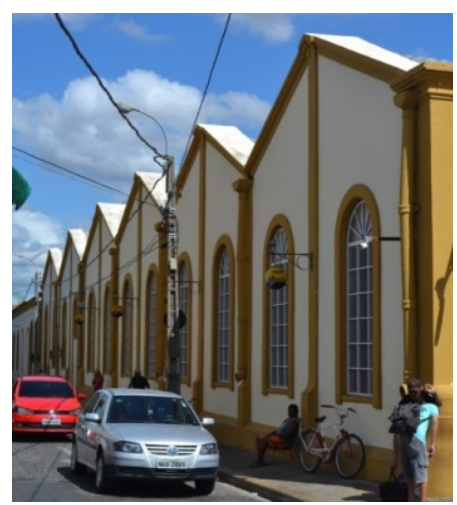

Figura 19. Calhas de descidas de água em ferro fundido. Fonte: Júlio de Paiva (2017).

O apelo a motivos ornamentais dá-se de forma seletiva e econômica, ao privilegiar as construções mais significativas do conjunto e restringir os ornatos, geralmente a simples apliques, concentrados, muitas vezes, nas platibandas dos prédios (Correia, 2011, p. 26).

0 prédio da fábrica possui uma fachada organizada em base, corpo e coroamento, em um emprego simplificado do estilo neoclássico. A referência à linguagem clássica pode ser identificada a partir da presença de esquadrias em arco pleno, cornija, cunhal e pilastras. Segue, assim, a linguagem adotada pela fábrica têxtil da vizinha Caxias (Figura 21) e por prédios institucionais de Teresina, como o Mercado Público (Figura 20) e o casarão da Família Almendra, que depois serviu por décadas de Palácio do Governo.

Era comum na época, as grandes industriais se responsabilizarem pela educação primária de seus operários, pelo interesse em ter trabalhadores alfabetizados (Stein, 1979). No caso em estudo, a situação não foi diferente. 0 jornal 0 Diário do Piauhy, do dia 25 de abril de 1911, comunicou a existência de uma escola noturna masculina para os sócios, filhos e parentes, mantida pela Sociedade Auxiliadora dos Empregados de Fiação e Tecidos Piauhyense, entidade provavelmente mantida pela empresa (Oficio, Diário do Piauhy, 1911).

Não foi possível obter maiores informações sobre a Sociedade Auxiliadora, mas sim indícios da existência da Liga Protectora dos Empregados de Fiação e Tecidos Piauhyense (Esforço, O Apostolo, 1907) e publicações sobre o Estatuto da Liga Protectora Operária - aparentemente fundada em 
1902 - que assegurava alguns serviços aos trabalhadores em troca de uma mensalidade (Estatutos, Diario do Piauhy, 1911).

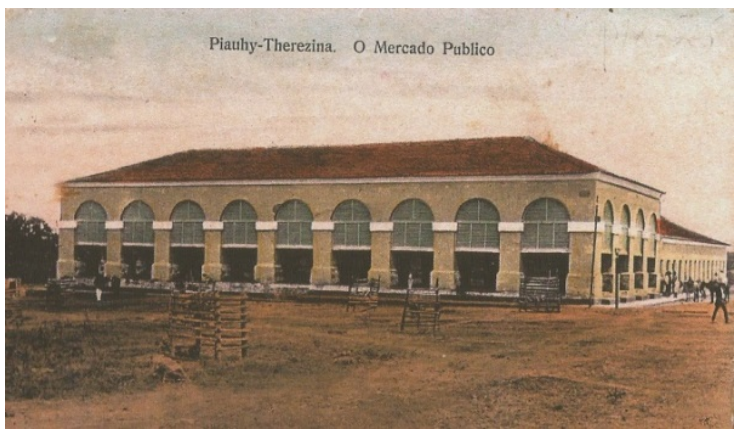

Figura 20. Mercado Público. Fonte: Silva Filho, 2007b.

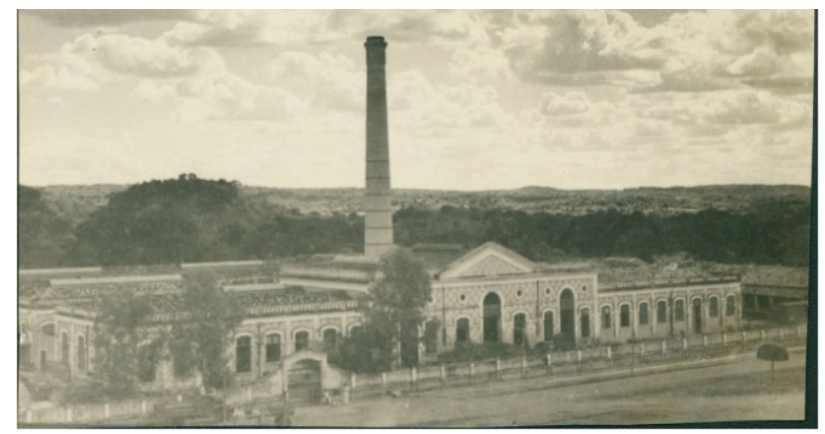

Figura 21. União Caxiense. Fonte: IBGE, 2017.

A Fábrica não proveu moradias para seus operários, como era comum em fábricas têxteis, mas suscitou a origem de um conjunto de moradias populares no seu entorno. Com a implantação do prédio da Fiação formou-se um vazio entre a Rua da Estrela e o norte da cidade de Teresina, região que foi escolhida para a edificação dessas casas:

A instalação da Companhia de Fiação e Tecidos Piauienses [...] entre a Baixa da Égua e o rio Parnaíba, no final do século XIX, contribuiu para aumentar o povoamento desse trecho da cidade pelos operários, que foram se fixando a partir do muro da fábrica na margem do rio, formando a Rua das Pedras, atual João Cabral com umas casas de estrutura precária que poderiam hoje ser comparadas aos barracos de favela (Lima, 2002, p.187).

Os limites do prédio e do muro da fábrica direcionaram a ocupação da área, definindo a linha de delimitação que formaria uma rua, seguindo o alinhamento do muro para direcionar suas casas a leste. 0 plano de Saraiva para cidade de Teresina previa quarteirões de 20 braças, mas naquela região não havia sido respeitado. A lateral leste da Rua João Cabral alongou-se até ficar emparelhada como muro e o prédio da fábrica, formando um beco de "vivendas dos favelados, operários da fábrica" (Monteiro, 1987c, p.267).

Nas primeiras três décadas do século XX, Teresina ainda estava compreendida entre a margem do Parnaíba e a Igreja São Benedito, "convivendo, no mesmo espaço, casas de telha e casebres de palha” (Lima, Santos; 2014, p.24). Monteiro diz que as casas de melhor condição, com cobertura cerâmica, estavam concentradas principalmente alinhadas ao muro da fábrica e no caminho que dava para o rio. A essa época, a ocupação da cidade se dava de forma mais concentrada às margens do rio Parnaíba "nas duas ou três ruas paralelas à margem" (Monteiro, 1988a, p.325).

Contudo, o tráfego nas margens do rio, se resumia a uma "via pública que se estreitara pelo calça-mento do talude da margem, posterior a cessão dos quarteirões" quando da fundação da cidade (Monteiro, 1988a, p.332). 0 muro da fábrica interrompia o acesso ao rio na Rua Benjamin Constant:

O muro margeava o rio à pequena distância. A erosão das chuvas cavava ravinas. Sobre as voçorocas ficavam pontilhões de paus roliços que desafiavam a perícia de equilibrismo $e$ arte de saltimbancos. Fazia-se verdadeiro malabarismo para transpor as barrocas sobre pinguelas (Monteiro, 1987c, p.259).

Durante a gestão do prefeito Domingos Monteiro, entre 1929 e 1930, iniciou-se um processo de reforma da cidade. Foram abertas novas ruas e avenidas, os serviços públicos foram expandidos. Junto à Fiação foi construída uma praça e abriu-se a via marginal ao rio, a Avenida Maranhão, com obras de drenagem urbana e construção de uma galeria de águas pluviais (Monteiro, 1987c). Comandando a Fiação, o Dr. Arêa Leão solicitou à Intendência que "extinga os abusos" dos operários e defina as dimensões oficiais das quadras e largura das ruas:

Com a sua influência e relacionamento fez com que a Prefeitura desse cadência urbanista àquela parte da cidade, além do traçado original do Governador Saraiva. Surgiram assim as ruas dispondo os alinhamentos das vias públicas e delimitação de uma praça, Três Corações. As quadras em retângulos. Não seria mais conveniente impor o quadrado do 
quarteirão primitivo com 40 braças de lado, nem permaneceu a largura de 11 metros para a rua, pela transformação das 5 braças de 2,20 metros o sistema métrico decimal (Monteiro, 1987c, p.260).

Houve uma "urbanização da favela operária", uma operação de grandes proporções, que contou com o auxílio da administração da fábrica (Monteiro, 1987c). Nela, muitas das casas dos operários da Fiação foram demolidas, deslocando seus moradores para bairros periféricos. Orgmar Monteiro (1987c) relata a demolição dessas casas para a abertura das ruas Benjamin Constant e Campos Sales. Ao mesmo tempo, ocorria, em 1928, a doação de terrenos em local periférico pela prefeitura aos operários da cidade, para que construíssem suas casas. Formou-se, assim, um bairro operário, que iniciou sua ocupação apenas em 1932. Esse bairro passou a se chamar Vila Operária, uma clara referência à produção habitacional relacionada ao desenvolvimento da indústria. Ao poder público coube os trâmites legais da doação dos terrenos, à fábrica a colaboração na retirada das casas junto a seus muros; a demarcação das ruas e lotes e o sorteio destes ficou sob responsabilidade da Aliança Federativa dos Obreiros do Piauí; a construção das casas coube aos próprios operários (Lima, Santos; 2014).

Sobre as moradias produzidas nesse bairro (Figura 22), Nascimento (2002) traz relatos de antigos moradores, que as descrevem como, muitas vezes, feitas de taipa e cobertas de palha. Durante muito tempo teve uma igreja, uma praça e um centro social mantido pelos operários. 0 poder público garantiu a construção de alguns equipamentos públicos - mercado, posto de saúde e farmácia - com a condição de uma quantidade mínima de casas de telha construídas (Lima, Santos; 2014). Assim, a partir da década de 1950, "as antigas casas foram substituídas por outras, modernas e elegantes. Foi mantido o pa-

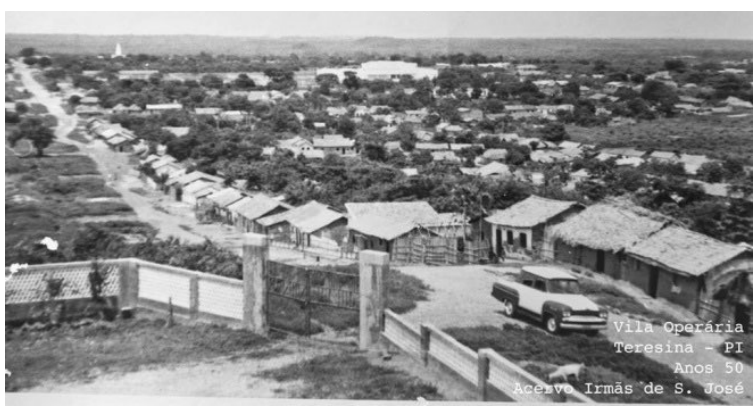

Figura 22. Imagem aérea da Vila Operária, década de 1950. Fonte: Acervo das Irmãs de São José. drão do traçado das ruas em tabuleiro de xadrez, alterando-se, porém a metragem das quadras" (Lima, 2002, p.187).

\section{Considerações Finais}

Embora, frequentemente, lembrado pela sua economia agrária, ligada ao algodão e ao gado, o Piauí teve a organização do seu território e de sua malha urbana, em grande parte associada às demandas da indústria. Sua economia foi profundamente afetada pela Revolução Industrial, tanto pelo fornecimento de matéria-prima - algodão, couro, etc. - para a indústria, quanto pelas fábricas criadas no Estado.

A fundação da nova capital - Teresina - esteve associada a demandas de transportes, vinculadas aos fluxos comerciais de matérias-primas e de mercadorias impulsionados pela indústria. Planejada sob a égide do urbanismo da retícula e da higiene do século XIX, Teresina foi uma cidade administrativa e um importante centro comercial e de serviços. Suas igrejas e repartições públicas espelhavam sua função de centro de poder, enquanto as casas comerciais atraídas pelo cais, seu papel de centro de distribuição de mercadorias.

Contudo, inserida na trama da economia capitalista, Teresina, sobretudo entre as últimas décadas do século XIX e as primeiras do XX, abrigou várias fábricas. Seu parque industrial, apesar de formado - salvo exceções - por fábricas de pequeno porte, era bastante diversificado. Incluía fábricas de sabão, tecidos, bebidas, calçados, charutos, cigarros, gelo e vinagre, laticínios, cerâmicas, usinas de açúcar e indústrias de beneficiamento de algodão e arroz.

Estas indústrias causaram profundos impactos no cotidiano e na forma da cidade. Geraram novos bairros - como o Núcleo Urbano Santana e o Bairro Vila Operária - onde se concentraram precárias moradias habitadas por trabalhadores. No cenário urbano, introduziram chaminés e novas tipologias construtivas. Seus galpões de fachadas mais ou menos amplas e pouco ornamentadas testemunhavam a inserção da cidade no mundo da produção industrial. Por sua vez, lojas instaladas em rebuscados prédios ecléticas traduziam outro viés desse mundo, o apelo ao consumo. 
Desta fase da história de Teresina, restaram vários prédios institucionais e poucos prédios industriais, como o da Companhia de Fiação e Tecidos, o da Companhia de Fiação e Tecidos Piauiense. Esse prédio, após passar alguns anos fechado e sem uso, foi adquirido pelo Grupo Claudino e passou a abrigar a matriz de uma das maiores redes de lojas de departamento do Piauí. 0 uso contribuiu para se encontrar bem conservado, embora alterado internamente em vários aspectos. A cobertura de telha cerâmica foi substituída por telhas metálicas, vãos foram fechados e muitas esquadrias substituídas.

O prédio está situado na única zona atualmente considerada de interesse de preservação patrimonial (ZP1) pela legislação municipal urbana em vigor. Esta zona corresponde ao centro histórico da cidade e à área traçada em sua fundação, onde se instalaram os prédios públicos e alguns privados julgados relevantes, como o da Fiação. Tal legislação prevê a proteção unicamente da fachada e delega ao órgão municipal de preservação do patrimônio a aprovação de toda e qualquer reforma e modificação no prédio. 0 prédio da fábrica, contudo, não possui proteção nas esferas estadual e federal. Embora não seja um exemplar excepcional de arquitetura, esse prédio é relevante para a história do Piauí e de Teresina, como testemunho de um muito pouco conhecido segmento industrial da economia local nas primeiras décadas de existência da cidade.

\section{Referências}

Acção Social. (1909, junho 27). O Apostolo: Orgam Official da Diocese, Theresina, p.3.

Almanak Administrativo, Mercantil e Industrial do Rio De Janeiro. (1891) Indústria. Rio de Janeiro: Companhia Typographica do Brasil.

Almanak Administrativo, Mercantil e Industrial do Rio De Janeiro. (1935). Indústria. Rio de Janeiro: Companhia Typographica do Brasil.

Anno. (1871, maio 6). A Imprensa., Theresina, p.1.

Annuncio. (1891, maio 21). A Legalidade, Therezina, p.4.

Annuncios. (1880, agosto 21). A Imprensa, p.3.

Annuncios. (1871, janeiro 12). A Imprensa, Theresina, p.4.

Annuncios (1909, maio 23). O Apostolo, Theresina, p.1.

Assembleia Provincial. (1888, agosto 11). A Imprensa, Theresina, 11 de agosto de 1888.

Barbosa, E. G. C. B. (1991). Therezina Teresina. Teresina: Fundação Cultural Monsenhor Chaves.

Barreto, P. T. (1975). O Piauí e sua Arquitetura. In: FAU/USP - MEC/IPHAN: Arquitetura Civil I: textos escolhidos da Revista do Instituto do Patrimônio Histórico e Artístico Nacional. São Paulo: FAU/USP.

Castello Branco Filho, M. (1978). A Habitação: Arquitetura Colonial do Piauí. Teresina.

Chaves, M. (2013). Obra Completa. Teresina: Fundação Municipal de Cultura Monsenhor Chaves.

Correia, T. B. (2011). Ornato e despojamento no mundo fabril. Anais do Museu Paulista. São Paulo. N. Sér. v.19. n.1. p. 11-79.

Dias, C. C. (2006). Piauhy das origens à nova Capital. Teresina: Nova Expansão Gráfica e Editora Ltda., 2006.

Directoria da Companhia. (1890, março 16). Estado do Piauhy, p.6.

Directoria da Fiação. (1910, setembro 4). 0 Apostolo, Theresina, p.3.

(C) Labor \& Engenho, Campinas [SP] Brasil, v.12, n.3, p.359-377, jul./set. 2018. 
Esforço Histórico. (1907, dezembro 8). O Apostolo, Theresina, p.4.

Estatutos da Sociedade Beneficente. (1911, setembro 28). Diario do Piauhy, Theresina, p.3.

Fabrica Estrella. (1907, novembro 17). 0 Commercio. p.3.

Fabrica. (1982, agosto 20). A Legalidade, Therezina, p.4.

Fabrica. (1889, março 7). A Phalange, Theresina, p.4.

Fiação e Tecidos. (1892a, novembro 26). A Legalidade, Therezina, p.4.

Fiação. A Legalidade, Therezina, 21 de novembro de 1892b, p.3.

Freire da Silva, A. (1911, junho 1). Diário do Piauhy. Therezina, p.4.

Hardman, F. F.; Leonardi, V. (1982). História da indústria e do trabalho no Brasil: das origens aos anos vinte. São Paulo: Global Editora.

Lançamento de imposto. (1912, maio 29). Diario do Piauhy. Therezina, p.3.

Lançamento de imposto. (1912, fevereiro 16). Diario do Piauhy. Therezina, p.2.

Lima, I. M. M. F. (2002). Teresina: urbanização e meio ambiente. Scientia et Spes. Revista do Instituto Camillo Filho. V.1, no 2. Teresina: ICF, p. 181-206.

Lima, S. O.; Santos, J. M. M. (2014). Classe Trabalhadora e Espaço Urbano: o surgimento do bairro Vila Operária em Teresina - Piauí (1928-1950). Informe Econômico. Ano 16, n.33. Teresina: UFPI, p. 23-27.

Magalhães, C. M. (2006). Mundos do Capital e do Trabalho: a construção da paisagem fabril itabirana. Dissertação de Mestrado, Programa de Pós-Graduação em História - UFMG.

Mendes, F. (2003). Economia e Desenvolvimento do Piauí. Teresina: Fundação Municipal Monsenhor Chaves, 2003.

Monteiro, Orgmar. (1987b). Teresina descalça: memória desta cidade para deleite dos velhos habitantes e conhecimentos dos novos. Fortaleza: Ioce, v. 2.

Monteiro, Orgmar. (1987c). Teresina descalça: memória desta cidade para deleite dos velhos habitantes e conhecimentos dos novos. Fortaleza: Ioce, v. 3.

Morto notável. (1910, dezembro 18). O Apostolo, Theresina, p.1.

Nascimento, F. A. (2002). A cidade sob o fogo: modernização e violência policial em Teresina (1937-1945). Teresina: Fundação Monsenhor Chaves.

No Pirajá.(1913, novembro 2). Diario do Piauhy. Theresina, p.2.

Noticiario. (1870, outubro 27). A Imprensa. Theresina, p.3.

Officios. (1880a, setembro 11). A Imprensa: Orgão do Partido Liberal. Therezina, p.2.

Officios (1880b, setembro 30). A Imprensa: Orgão do Partido Liberal. Therezina, p.5.

Officio (1911, fevereiro 27). Diario do Piauhy, Therezina, p.3.

Oficio. (1911, abril 25). Diário do Piauhy, Theresina, p.2.

(C) Labor \& Engenho, Campinas [SP] Brasil, v.12, n.3, p.359-377, jul./set. 2018. 
Rodrigues, J. L. P. (2001) Estudos Regionais do Piauí. Teresina: Halley.

Silva Filho, O. P. (2007b). Carnaúba, pedra e barro na Capitania de São José do Piauhy, vol. 2, Belo Horizonte.

Silveira, T. C. (2013). Desvelando os Caminhos do Santana: História e Memória de um Processo de Rurbanização. 166f. Dissertação (Mestrado em História do Brasil). Universidade Federal do Piauí, Teresina, Piauí, Brasil.

Sociedade De Agricultura. (1908, fevereiro 16). O Apóstolo. 16 de fevereiro de 1908, p.3.

Stein, S. J. (1979). Origens e Evolução da Indústria Têxtil no Brasil - 1850/1950. Rio de Janeiro: Editora Campus Ltda., 1979.

Vallente. (1892, junho 25). A Legalidade, Therezina, p.4. 